\title{
EFFECT OF COMPOSITION AND PREPARATION METHOD OF (Pd), Co, Ce, Zr - METAL-OXIDE CATALYSTS ON THEIR ACTIVITY IN THE REDUCTION OF NITROGEN(I), (II) OXIDES WITH CARBON MONOXIDE
}

\author{
T.M. Boichuk *, P I. Kirienko, S.M. Orlyk, S.O. Soloviev \\ L.V. Pisarzhevsky Institute of Physical Chemistry of National Academy of Sciences of Ukraine \\ 31 Nauki Pr., Kiev, 03039, Ukraine
}

\begin{abstract}
Among the studied (Pd), Co-, Ce-, Zr-oxide catalysts including catalysts deposited on structured cordierite support, the catalyst prepared by co-deposition of ceria and cobalt oxide is characterized by higher activity in reaction of reduction of nitrogen(I), (II) oxides $\left(\mathrm{CO}+\mathrm{NO}, \mathrm{N}_{2} \mathrm{O}+\mathrm{NO}+\mathrm{CO}\right)$ compared with samples prepared by successive deposition. This may be caused by an increase in both mobility of surface oxygen and dispersity of components in the catalytic composition.
\end{abstract}

\section{INTRODUCTION}

One of the most important challenges for scientific and applied researches is reduction of nitrogen oxides $\left(\mathrm{NO}_{\mathrm{x}}\right)$ in gas emissions mobile and stationary sources, as evidenced by the introduction of morestrict norms for emissions into the environment (EURO-V). The emission of nitrogen oxides $\mathrm{NO}_{\mathrm{x}}\left(\mathrm{NO}, \mathrm{NO}_{2}\right.$ and $\left.\mathrm{N}_{2} \mathrm{O}\right)$ into the atmosphere is 30 million tons annually. Nitrogen oxides are involved into atmospheric processes that lead to depletion of ozone layer bringing about "greenhouse" effect and the formation of acid rain, smog [1]. One of the most efficient methods for neutralization of nitrogen oxides $\mathrm{NO}_{\mathrm{x}}$ in exhaust gases is catalytic reduction with various reducing agents $\left(\mathrm{CO}\right.$ and $\left.\mathrm{C}_{\mathrm{n}} \mathrm{H}_{\mathrm{m}}\right)$.

Platinum group metals ( $\mathrm{PGM})(\mathrm{Pt}, \mathrm{Pd}, \mathrm{Rh})$ in the composition of TWC catalysts $\left(\mathrm{CO} / \mathrm{NO} / \mathrm{C}_{\mathrm{n}} \mathrm{H}_{\mathrm{m}}\right)$ are active for the reactions of $\mathrm{CO}+\mathrm{NO}\left(\mathrm{N}_{2} \mathrm{O}\right)$. One the way for reducing of the PGM content is their partial replacement by other substances such as transition metal oxides with high mobility of surface oxygen $[2,3]$. Rare earth oxide (REO) doping may increase the activity of transition metal oxide catalysts. It is known that the catalytic systems containing cobalt oxide $\left(\mathrm{Co}_{3} \mathrm{O}_{4}\right)$ with REO $\left(\mathrm{CeO}_{2}, \mathrm{La}_{2} \mathrm{O}_{3}\right)$, which demonstrate high activity in oxidation of $\mathrm{CO}$, hydrocarbons and in reduction of $\mathrm{NO}$, may be used for purification of automobile exhaust gases [4-7]. The high catalytic activity of $\mathrm{Co}_{3} \mathrm{O}_{4}$ and $\mathrm{CeO}_{2}$ mixtures is attributed to the formation of Co-O-Ce surface clusters during preparation $[4,8]$.

Now the main attention is focused on structured catalysts in the form of monolithic blocks, in particular, because of the wide selection of options for constructive solutions, low gasdynamic resistance, easy placement in reactor [9].

This paper presents the results of study of the effect of composition of palladium-cobalt-ceriumoxide catalysts supported on zirconia as well as over structured honeycomb monoliths $\mathrm{Pd} /\left(\mathrm{Co}_{3} \mathrm{O}_{4}+\mathrm{CeO}_{2}+\left(\mathrm{ZrO}_{2}\right)\right) /$ cordierite on their activity in the reduction of nitrogen(I),(II) oxides with carbon monoxide. Structure-sized characteristics (phase composition, dispersion) and redox properties of the composites $\mathrm{Pd} / \mathrm{CeO}_{2^{-}}$ $\mathrm{Co}_{3} \mathrm{O}_{4} /$ cordierite (with different preparation methods) and their effect on the catalytic properties of metal-oxide catalysts were also studied.

\section{EXPERIMENTAL}

Monolithic ceramic blocks of synthetic cordierite $\left(2 \mathrm{Al}_{2} \mathrm{O}_{3} \cdot 2 \mathrm{MgO} \cdot 5 \mathrm{SiO}_{2}\right)$ with a honeycomb structure and zirconia (specification 6-09-2486-77) were used as a catalyst support. The main characteristics of cordierite monolith were described in [10]. The formation of catalytic coating catalysts was carried by impregnation (in the case of cordierite - on moisture capacity) from aqueous solution of $\left(\mathrm{NH}_{4}\right)_{2} \mathrm{Ce}\left(\mathrm{NO}_{3}\right)_{6}$, $\mathrm{Co}\left(\mathrm{NO}_{3}\right)_{2} \cdot 6 \mathrm{H}_{2} \mathrm{O}, \mathrm{Pd}\left(\mathrm{NO}_{3}\right)_{2}$ followed by drying in air at $110^{\circ} \mathrm{C}$ and calcining at $600{ }^{\circ} \mathrm{C}$. The 
multicomponent catalysts were prepared by the deposition of the active components in the following order: (1) cerium oxide, cobalt oxide (successive deposition, SD), palladium; (2) cerium oxide with cobalt oxide (co-deposition, CD), palladium. The following catalyst samples formed on cordierite and zirconia were prepared: $0.1 \% \mathrm{Pd} / 5 \% \mathrm{Co}_{3} \mathrm{O}_{4}$

$0.1 \% \mathrm{Pd} / 2 \% \mathrm{Co}_{3} \mathrm{O}_{4}+3.5 \% \mathrm{CeO}_{2}(\mathrm{CD})$,

$0.1 \% \mathrm{Pd} / 2 \% \mathrm{Co}_{3} \mathrm{O}_{4} / 3.5 \% \mathrm{CeO}_{2}$ (SD),

$0.1 \% \mathrm{Pd} / 2 \% \mathrm{Co}_{3} \mathrm{O}_{4}+2.7 \% \mathrm{CeO}_{2}+0.8 \% \mathrm{ZrO}_{2}(\mathrm{CD})$.

Bulk samples with the same ratios and the same order of component deposition as for the supported catalysts were prepared to evaluate structural, dimensional characteristics and morphology of the catalyst surface by X-ray diffraction and transmission electron microscopy.

The catalytic activity of the samples was characterized by the conversion of $\mathrm{N}_{2} \mathrm{O}$ and $\mathrm{NO}$ to nitrogen which was determined in a continuous-flow system with a gradientless quartz reactor under atmospheric pressure in the temperature range $150-400{ }^{\circ} \mathrm{C}$. The following reaction mixtures were used (vol. \%): $\mathrm{N}_{2} \mathrm{O}-0.2$; $\mathrm{NO}-0.2 ; \mathrm{CO}-0.2$ and 0.8 ; the rest - helium. Gas hour space velocity was $6.000 \mathrm{~h}^{-1}$. The sample (fraction 1-3 mm) was roasted prior to testing at $550{ }^{\circ} \mathrm{C}$ for $1 \mathrm{~h}$. The structured catalysts were tested in reaction $\mathrm{NO}+\mathrm{CO}$ in a flow reactor with gas hour space velocity $20.000 \mathrm{~h}^{-1}$ on a catalyst block fragment $(8 \mathrm{~mm}$ in diameter $\times 13 \mathrm{~mm}$ in length with density 49 cells $/ \mathrm{cm}^{2}, \quad 0.3 \mathrm{~g}$ ). The components and reaction products were analyzed by gas chromatography (Kristallyuks 4000M, Metachrom, Russia) with conductometer detector and CaA column (for $\mathrm{N}_{2}, \mathrm{NO}, \mathrm{CO}, \mathrm{O}_{2}$ ), Polisorb-1 column (for $\mathrm{N}_{2} \mathrm{O}, \mathrm{CO}_{2}$ ).

The oxidation-reduction properties of the catalysts were studied by temperature programmed reduction with hydrogen $\left(\mathrm{TPR}-\mathrm{H}_{2}\right)$ in a flow system with continuous chromatographic monitoring of the amount of hydrogen consumed in the reduction. The gas mixture contained was 10 vol. $\% \mathrm{H}_{2}$ in argon. The temperature was raised from 20 to $650{ }^{\circ} \mathrm{C}$ with the heating temperature rate $17^{\circ} \mathrm{C} / \mathrm{min}$. The mass of catalyst was $0.5 \mathrm{~g}$.

$\mathrm{X}$-ray diffraction (XRD) patterns of the powder samples were recorded using diffractometer with monochromatized $\mathrm{Cu}-\mathrm{K} \alpha$ radiation (nickel filter, $\lambda=0.15184 \mathrm{~nm}) \quad(\mathrm{AXS} \quad \mathrm{GmbH} \quad$ D8 Advance diffractometer, Bruker, Germany).

The morphology of the sample surface was studied using transmission electron microscope (TEM) (Selmi TEM-125K, Selmi, Ukraine). The specific surface $\left(\mathrm{S}_{\mathrm{sp}}, \mathrm{m}^{2} / \mathrm{g}\right)$ was determined chromatographically by thermal argon desorption on a GKh-1 instrument.

\section{RESULTS AND DISCUSSION}

The activity of the (Pd), Co-, Ce-, $\mathrm{Zr}$-oxides catalysts, also over the monoliths with honeycomb structure, in reactions of nitrogen(I), (II) oxides reduction with carbon monoxide is presented in the Table.

Table. Catalytic activity of (Pd), Co-, Ce-, $\mathrm{Zr}$-oxides catalysts in reactions of nitrogen(I) (II) oxides reduction by carbon monoxide $\left(\mathrm{V}=6.000 \mathrm{~h}^{-1}\right)$

\begin{tabular}{|c|c|c|c|}
\hline \multirow{2}{*}{$\begin{array}{c}\text { Catalyst } \\
\text { (method of preparation) }\end{array}$} & \multicolumn{3}{|c|}{$\begin{array}{l}\mathrm{N}_{2} \mathrm{O}[\mathrm{NO}] \text { conversion, \% / } \mathrm{T}{ }^{\circ} \mathrm{C}\left(\mathrm{T}_{50 \%}\right) \\
\text { for indicated reaction mixtures: }\end{array}$} \\
\hline & $\mathrm{S}_{\mathrm{sp}}, \mathrm{m}^{2} / \mathrm{g}$ & $0.2 \% \mathrm{~N}_{2} \mathrm{O}+0.2 \% \mathrm{NO}+0.8 \% \mathrm{CO}$ & $0.2 \% \mathrm{CO}+0.2 \% \mathrm{NO}$ \\
\hline $5 \% \mathrm{Co}_{3} \mathrm{O}_{4} / \mathrm{ZrO}_{2}$ & 6.7 & $83 / 400(270)[82 / 250]$ & - \\
\hline $0.1 \% \mathrm{Pd} / 5 \% \mathrm{Co}_{3} \mathrm{O}_{4} / \mathrm{ZrO}_{2}$ & 5.7 & $85 / 350(200)[99 / 200]$ & - \\
\hline $\begin{array}{l}0.1 \% \mathrm{Pd} / 2 \% \mathrm{Co}_{3} \mathrm{O}_{4}+ \\
3.5 \% \mathrm{CeO}_{2} / \mathrm{ZrO}_{2}(\mathrm{CD})\end{array}$ & 5.8 & $85 / 300(190)[99 / 160]$ & - \\
\hline $0.1 \% \mathrm{Pd} / 5 \% \mathrm{Co}_{3} \mathrm{O}_{4} /$ cordierite & 1.5 & $78 / 350(275)[99 / 300]$ & $99 / 250(230)$ \\
\hline $\begin{array}{l}0.1 \% \mathrm{Pd} / 2 \% \mathrm{Co}_{3} \mathrm{O}_{4}+ \\
3.5 \% \mathrm{CeO}_{2} / \text { cordierite }(\mathrm{CD})\end{array}$ & 2.7 & $78 / 300(180)[99 / 200]$ & $99 / 155(123)$ \\
\hline $\begin{array}{l}0.1 \% \mathrm{Pd} / 2 \% \mathrm{Co}_{3} \mathrm{O}_{4} / \\
3.5 \% \mathrm{CeO}_{2} / \text { cordierite }(\mathrm{SD})\end{array}$ & 2.2 & - & $99 / 200(169)$ \\
\hline $\begin{array}{l}0.1 \% \mathrm{Pd} / 2 \% \mathrm{Co}_{3} \mathrm{O}_{4}+2.7 \% \mathrm{CeO}_{2} \\
+0.8 \% \mathrm{ZrO}_{2} / \text { cordierite }(\mathrm{CD})\end{array}$ & 3.5 & $75 / 325(240)[99 / 260]$ & $99 / 190(130)$ \\
\hline
\end{tabular}

The cobalt-containing sample based on $\mathrm{ZrO}_{2}$ exhibited high activity in the reaction $\mathrm{N}_{2} \mathrm{O}+\mathrm{NO}+\mathrm{CO}$ : in the temperature range 250
$270{ }^{\circ} \mathrm{C}$ the conversion of $\mathrm{NO}, \mathrm{CO}$ and $\mathrm{N}_{2} \mathrm{O}$ is 82 , 90, and $50 \%$, respectively; the higher conversions of nitrogen(I) oxide $(83 \%)$ is 
achieved at higher temperature $-400{ }^{\circ} \mathrm{C}$. Introduction of palladium $(0.1 \%)$ into $5 \% \mathrm{Co}_{3} \mathrm{O}_{4} / \mathrm{ZrO}_{2}$ catalyst leads to an increase in its activity. High conversions of $\mathrm{NO}$ and $\mathrm{CO}$ $(90 \%)$ are achieved at lower temperatures (at $\sim 160{ }^{\circ} \mathrm{C}$ ) in the presence of cerium-containing sample $\mathrm{Pd} / \mathrm{Co}_{3} \mathrm{O}_{4}+\mathrm{CeO}_{2} / \mathrm{ZrO}_{2} ; 85 \%$ conversion of nitrogen(I) oxide is achieved at $300{ }^{\circ} \mathrm{C}$. The difference in temperatures of high conversion of nitrogen oxides under conditions of their combined reduction with carbon monoxide may be due to the competition of $\mathrm{N}_{2} \mathrm{O}$ and $\mathrm{NO}$ molecules for an active site of the catalyst as was observed in the combined reduction of $\mathrm{N}_{2} \mathrm{O}+\mathrm{NO}$ with $\mathrm{C}_{3}-\mathrm{C}_{4}$ alkanes [11].

The activity of palladium-doped catalysts formed on the surface of cordierite in reduction of $\mathrm{N}_{2} \mathrm{O}+\mathrm{NO}$ with $\mathrm{CO}$ is changed in following order:

$$
\mathrm{Co}_{3} \mathrm{O}_{4}-\mathrm{CeO}_{2}>\mathrm{Co}_{3} \mathrm{O}_{4}-\mathrm{CeO}_{2}-\mathrm{ZrO}_{2}>\mathrm{Co}_{3} \mathrm{O}_{4} \text {. }
$$

At the most active sample of structured catalyst $0.1 \% \mathrm{Pd} / 2 \% \mathrm{Co}_{3} \mathrm{O}_{4}+3.5 \% \mathrm{CeO}_{2} /$ cordierite $60-78 \%$ conversion of nitrous oxide and $99 \%$ conversion of nitrogen monoxide is achieved in the temperature range $200-300{ }^{\circ} \mathrm{C}$.

Decrease in $\mathrm{NO}$ and $\mathrm{N}_{2} \mathrm{O}$ conversion on the structured catalysts in comparison with granulated, probablly, is related to some decrease in specific and consequently also an active surface of the samples (Table).

Modification of the palladium-cobalt-oxide structured catalyst by cerium oxide enhances its activity in $\mathrm{CO}+\mathrm{NO}$ reaction. A more significant increase in catalytic activity is achieved by codeposition of cobalt oxide and cerium oxide, in comparison with successive deposition of the components (Table).

The dependence of the catalytic activity on the chemical composition and the method of preparation (CD or SD), i.e. on the order of deposition of the components may be caused by generation of various phases during formation of the catalytic composition. Bulk samples were studied by XPA to elucidate this question (Fig. 1).

The diffraction patterns of the cobalt-cerium oxide compositions showed only finely dispersed phases of $\mathrm{Co}_{3} \mathrm{O}_{4}$ (spinel structure $\left(\mathrm{CoCo}_{2} \mathrm{O}_{4}\right)$ $\left(2 \theta=18.95^{\circ} ; 31.35^{\circ} ; 36.90^{\circ} ; 44.90^{\circ} ; 59.40^{\circ}\right.$; $55.90^{\circ}$; 59.40) and $\mathrm{CeO}_{2}$ (fluorite structure) $\left(2 \theta=6.25^{\circ} ; 28.65^{\circ} ; 33.10^{\circ} ; 47.75^{\circ} ; 56.75^{\circ}\right.$; $59.05^{\circ}$ ) with mean particle diameter $26 \mathrm{~nm}$ for
$\mathrm{Co}_{3} \mathrm{O}_{4}$ and $14 \mathrm{~nm}$ for $\mathrm{CeO}_{2}$ (co-deposition of the components), and $55 \mathrm{~nm}$ for $\mathrm{Co}_{3} \mathrm{O}_{4}$ and $14 \mathrm{~nm}$ for $\mathrm{CeO}_{2}$ (successive deposition of the components). The mean particle diameter for pure cobalt oxide $\left(\mathrm{CoCo}_{2} \mathrm{O}_{4}\right)$ is $44 \mathrm{~nm}$. We should also note that the diffraction patterns of the cobalt-cerium oxide compositions show decreased intensity of the cobalt oxide peaks for compositions prepared by co-deposition of the components in comparison with compositions prepared by successive deposition of the components. Strong extinction characteristic reflexes that respond $\mathrm{Co}_{3} \mathrm{O}_{4}$ in the composition $\mathrm{Co}_{3} \mathrm{O}_{4}-\mathrm{CeO}_{2}$ (patterns 2 and 3) can also indicate the formation of solid solutions. The formation of a bulk crystalline structure derived from oxides $\mathrm{CeO}_{2}$ and $\mathrm{Co}_{3} \mathrm{O}_{4}$ proved impossible since the coordination numbers of the cerium and cobalt ions are different [12]. Such systems derived from $\mathrm{Ce}$ and $\mathrm{Fe}$ oxides were studied by Liu et al. [13] who found that the formation of solid solutions of $\mathrm{Ce}_{\mathrm{x}} \mathrm{Fe}_{1-\mathrm{x}} \mathrm{O}_{2}$ occured only for $\mathrm{x} \leq 0.2$ while a separate $\mathrm{Fe}_{2} \mathrm{O}_{3}$ phase was noted when $x>0.2$. Hence, we may propose that the increase in activity of the $\mathrm{Pd} / \mathrm{Co}_{3} \mathrm{O}_{4} /$ cordierite catalyst after cerium oxide doping occurs as a result of an interaction of the finely dispersed particles of the active components on the phase boundary with formation of solid solutions which facilitates diffusion of oxygen from $\mathrm{CeO}_{2}$ to $\mathrm{Co}_{3} \mathrm{O}_{4}[4,6,7]$.

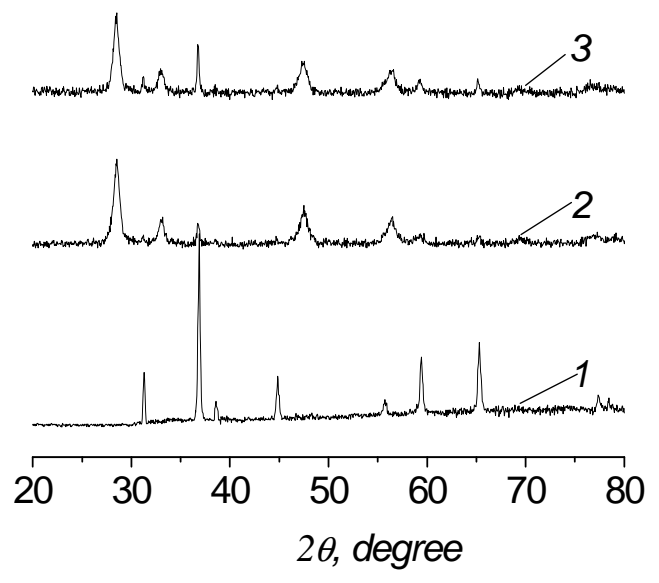

Fig. 1. XRD patterns of bulk samples of catalysts: $1-\mathrm{Co}_{3} \mathrm{O}_{4} ; \quad 2-\mathrm{Co}_{3} \mathrm{O}_{4}+\mathrm{CeO}_{2}(\mathrm{CD}) ; \quad 3-$ $\mathrm{Co}_{3} \mathrm{O}_{4} / \mathrm{CeO}_{2}(\mathrm{SD})$

It is known that doping of cobalt oxide spinel structure with a small amount of cerium oxide $(\mathrm{Ce} / \mathrm{Co}=0.05)$ increases the surface $\mathrm{Co}_{3} \mathrm{O}_{4}$ and assists the reduction $\mathrm{Co}^{3+}$ to $\mathrm{Co}^{2+}$, thus facilitating 
the desorption of surface oxygen - the limiting stage of nitrous oxide decomposition on the catalysts of this type [14]. Cobalt is stabilized on the separation boundary between $\mathrm{Co}_{3} \mathrm{O}_{4}$ and $\mathrm{CeO}_{2}$ in an oxidation state higher than stoichiometric, there is an increase in the $\mathrm{Co}-\mathrm{O}$ bond length at the sites of contact of the cobalt and cerium nanoparticles and the surface oxygen on the interface between of the oxide phases becomes more mobile than the bulk oxygen of the individual oxides [4].

According to IR spectroscopy data (Fig. 2), absorption intensity at $572 \mathrm{~cm}^{-1}$ (bond $\mathrm{Co}^{3+}-\mathrm{O}$ [7]) for $\mathrm{Co}_{3} \mathrm{O}_{4}+\mathrm{CeO}_{2}$ (CD) sample is higher than that for individual cobalt oxide. At the same time, one can see that absorption intensity at $663 \mathrm{~cm}^{-1}$ (bond $\mathrm{Co}^{2+}-\mathrm{O}$ [7]) is decreased partially. This was not observed in the case of catalyst prepared by successive deposition of the components. So, preparation of the catalysts by co-deposition of cobalt and cerium oxides assist more intensive interaction and stabilization of $\mathrm{Co}^{3+}$ state which is more reactive in redox processes with oxygen.

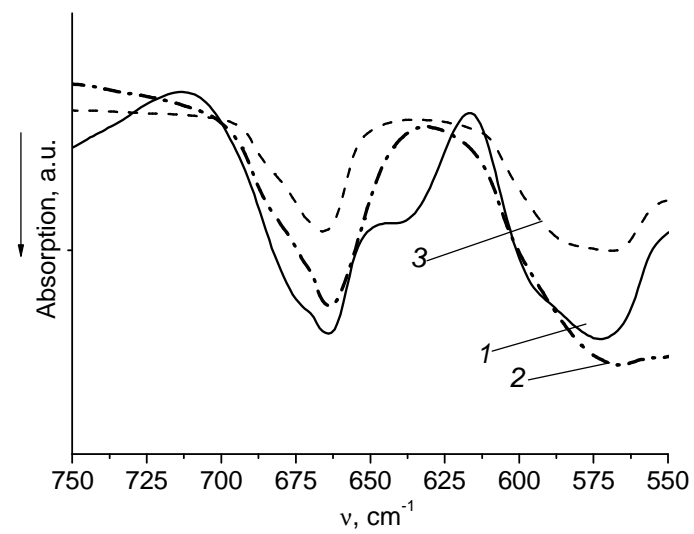

Fig. 2. IR-spectra of bulk samples of catalysts: $1-$ $\mathrm{Co}_{3} \mathrm{O}_{4} ; \quad 2-\mathrm{Co}_{3} \mathrm{O}_{4}+\mathrm{CeO}_{2} \quad(\mathrm{CD}) ; \quad 3-$ $\mathrm{Co}_{3} \mathrm{O}_{4} / \mathrm{CeO}_{2}(\mathrm{SD})$

Thus, the interaction between $\mathrm{CeO}_{2}$ and $\mathrm{Co}_{3} \mathrm{O}_{4}$ is more effective in the case of simultaneous introduction of $\mathrm{Co}_{3} \mathrm{O}_{4}$ and $\mathrm{CeO}_{2}-$ active components of the catalyst.

Analysis of the TEM photographs of the bulk samples shown in Fig. 3 indicates that a more dispersed phase is formed upon the joint introduction of the components into the catalytic composition (precursors of cobalt and cerium oxides) than in the case of pure $\mathrm{Co}_{3} \mathrm{O}_{4}$ oxide (Fig. $3 a, b$ ) while agglomeration of the $\mathrm{Co}_{3} \mathrm{O}_{4}$ and $\mathrm{CeO}_{2}$ particles occurs upon the consecutive introduction of the components with subsequent sintering at $600{ }^{\circ} \mathrm{C}$ already during the catalyst preparation step. The stabilizing role of cerium oxide is due to localization of this oxide between the cobalt oxide microcrystals preventing agglomeration of the binary oxide composition [15]. Further reducing of the crystallites size of the catalyst components is observed at the partial replacement of cerium oxide by zirconium oxide (Fig. $3 c$ ). Probably, zirconia prevents agglomeration of cerium oxide in the procedure of preparation and assists to increase the dispersion of the composition [16].

The results of a SEM study indicated a rather homogeneous distribution of the $\mathrm{Pd} / \mathrm{Co}_{3} \mathrm{O}_{4}$ and $\mathrm{Pd} /\left(\mathrm{Co}_{3} \mathrm{O}_{4}+\mathrm{CeO}_{2}\right)$ compositions on the cordierite surface. Formation of ring-like structures of the active components is observed for $0.1 \% \mathrm{Pd} /\left(\mathrm{Co}_{3} \mathrm{O}_{4}+\mathrm{CeO}_{2}\right) /$ cordierite (Fig. $3 e$ ). This may be taken as an argument to support the hypothesis that the components form a homogeneous structure containing a mixture of pure phases. These results are in accord with the XPA results and literature data $[6,7]$.

The values of the specific surface of the catalyst samples deposited on a structurized cordierite support and bulk samples indicate high dispersion of the active phase in the case of codeposition of $\mathrm{Co}_{3} \mathrm{O}_{4}$ and $\mathrm{CeO}_{2} \quad\left(\mathrm{ZrO}_{2}\right)$ components (Table).

The mechanism for the reduction of NO with carbon monoxide over platinum group metals, in particular over palladium, involves a step featuring the dissociative adsorption of nitric oxide (II) [17]. Bol'shakov et al. [2] have shown that palladium in the $\mathrm{Pd}-\mathrm{Co} / \gamma-\mathrm{Al}_{2} \mathrm{O}_{3}$ catalyst provides for spillover of the oxygen formed onto cobalt oxide where it reacts with carbon monoxide. As a consequence, oxygen passivation of the $\mathrm{Pd}-\mathrm{Co} / \gamma-\mathrm{Al}_{2} \mathrm{O}_{3}$ catalyst is overcome and high activity in the reduction of nitrogen oxides is achieved. Whereas modification of the palladium-cobalt oxide catalyst with cerium oxide increases activity in the reaction $\mathrm{NO}+\mathrm{CO}$, we may also assume that the addition of $\mathrm{CeO}_{2}$ to the $\mathrm{Pd}-\mathrm{Co}_{3} \mathrm{O}_{4}$ catalyst facilitates spillover of oxygen onto the cobalt oxide surface due to an increase in the number of oxygen vacancies on the separation boundary of the $\mathrm{Co}_{3} \mathrm{O}_{4}$ and $\mathrm{CeO}_{2}$ phases and a reduction in the bonding energy of the bond of oxygen to the surface. 
Platinum group metals are characterized by low metal-oxygen binding energy [3], so, oxygen is rapidly desorbed from the surface of such metals as a result of the reaction that occurs at lower temperatures.

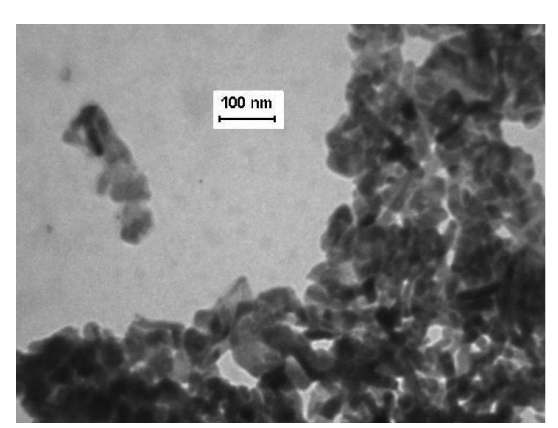

$a$

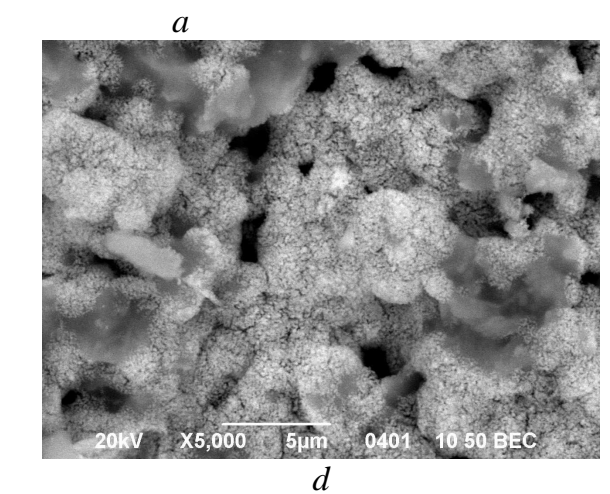

TPR- $\mathrm{H}_{2}$ experiments were carried out in order to study the redox properties of the catalysts; the results are displayed in Fig. 4.

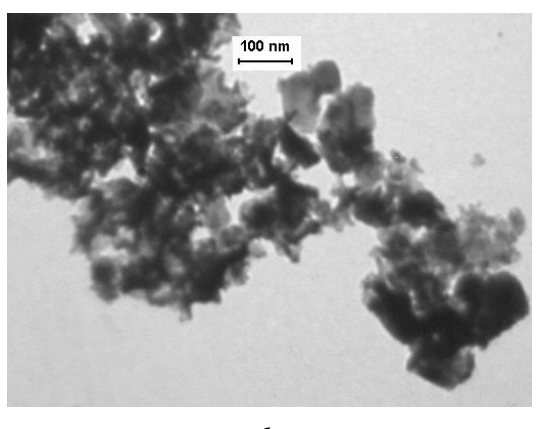

$b$

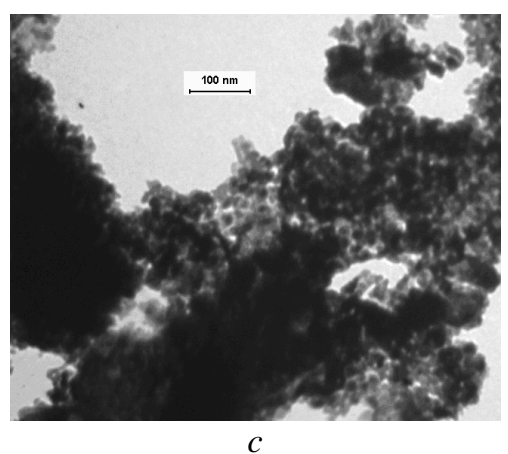

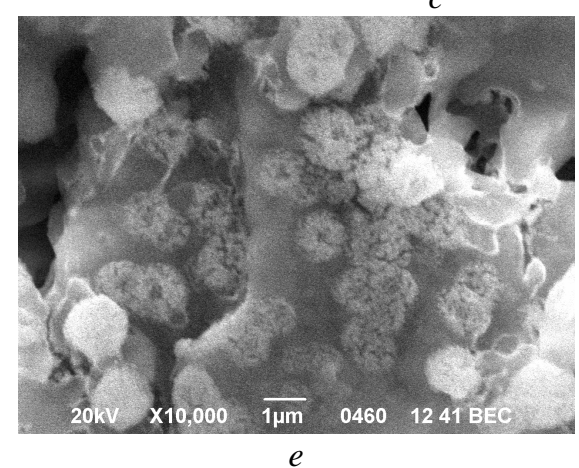

Fig. 3. TEM $(a-c)$ and SEM microphotographs $(d, e)$ of catalyst samples: (a) $\mathrm{Co}_{3} \mathrm{O}_{4} ;(b) \mathrm{Co}_{3} \mathrm{O}_{4}+\mathrm{CeO}_{2} ;(c)$ $\mathrm{Co}_{3} \mathrm{O}_{4}+\mathrm{CeO}_{2}+\mathrm{ZrO}_{2} ;(d) 0.1 \% \mathrm{Pd} / \mathrm{Co}_{3} \mathrm{O}_{4} /$ cordierite; (e) $0.1 \% \mathrm{Pd} / \mathrm{Co}_{3} \mathrm{O}_{4}+\mathrm{CeO}_{2} /$ cordierite

The introduction of palladium leads to a shift in the reduction onset temperature and maximum on the TPR- $\mathrm{H}_{2}$ curves toward lower temperatures. The TPR- $\mathrm{H}_{2}$ spectrum shows a new low-temperature peak $\left(180{ }^{\circ} \mathrm{C}\right)$ due to an increase in the mobility of surface oxygen while the concurrent increase in the area under the TPR- $\mathrm{H}_{2}$ curves indicates an increase in the number of active sites. A low-temperature peak in similar systems has been observed by Luo et al. [4] for the TPR of catalysts by carbon monoxide. The onset temperature and temperature for maximum reduction rate for the $\mathrm{Co}_{3} \mathrm{O}_{4}+\mathrm{CeO}_{2} /$ cordierite catalyst are 20 and $80{ }^{\circ} \mathrm{C}$, respectively, lower than those for the $\mathrm{Co}_{3} \mathrm{O}_{4} /$ cordierite sample. The values for $T_{1 \text { on }}$ and $T_{1 \text { max }}$ for $\mathrm{Pd} / \mathrm{Co}_{3} \mathrm{O}_{4}+\mathrm{CeO}_{2} /$ cordierite are 55 and $60{ }^{\circ} \mathrm{C}$, respectively, lower than those for the sample lacking the $\mathrm{CeO}_{2}$ modifying additive. This result indicates a higher mobility of oxygen at the interface between of the cerium oxide and cobalt oxide phases and accounts for the increase in the activity of the
$0.1 \% \mathrm{Pd} /\left(\mathrm{Co}_{3} \mathrm{O}_{4}+\mathrm{CeO}_{2}\right) /$ cordierite catalyst in the oxidation-reduction reactions involving nitrogen oxides(I), (II) studied.

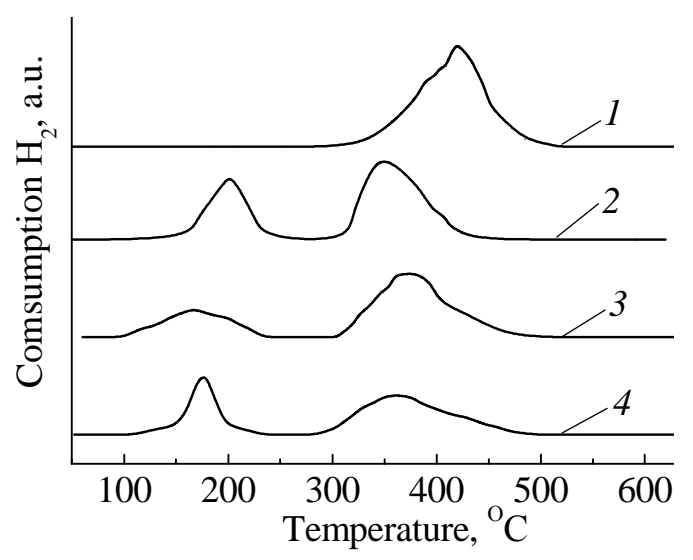

Fig. 4. TPR- $\mathrm{H}_{2}$ profiles of the cordierite-supported catalysts: $1-\mathrm{Co}_{3} \mathrm{O}_{4} ; 2-0.1 \% \mathrm{Pd} / 5 \% \mathrm{Co}_{3} \mathrm{O}_{4}$; $3-\mathrm{Co}_{3} \mathrm{O}_{4}+\mathrm{CeO}_{2}(\mathrm{CD}) ; 4-\mathrm{Co}_{3} \mathrm{O}_{4} / \mathrm{CeO}_{2}(\mathrm{SD})$

\section{CONCLUSIONS}

Modification of the palladium-cobalt oxide catalysts with cerium oxide enhances its activity 
in reaction of nitrogen(I), (II) oxides reduction with carbon monoxide and caused by increasing the mobility of surface oxygen of catalyst. The most significant increase in activity for the catalyst prepared by co-deposition of ceria and cobalt oxide takes place due to the more disperse components in the catalytic composition according to the results of XRD, TEM and SEM.

\section{REFERENCES}

1. The Introduction of Euro 5 and Euro 6 Emissions Regulations for Light Passenger and Commercial Vehicles. - http://www.rsa.ie/.

2. Bol'shakov A.M., Bol'shakova L.D., Shchegol'kov Yu.N. et al. Chimicheskoe konstruirovanie binarnih TWC-katalizatorov dlya konversii $\mathrm{NO}_{\mathrm{x}}, \mathrm{CO}$ i uglevodorodov // Khim. Interes. Ustoich. Razvit. - 2005. V. 13. - P. 737-742 (in Russian).

3. Golodets G.I. Geterogenno-kataliticheskie reaktsii s uchastiem molekulyarnogo kisloroda. Heterogeneously Catalyzed Reactions Involving Molecular Oxygen. - Kyiv: Naukova Dumka, 1977. - 360 p. (in Russian).

4. Luo J.Y., Meng M., Li X. et al. Mesoporous $\mathrm{Co}_{3} \mathrm{O}_{4}-\mathrm{CeO}_{2}$ and $\mathrm{Pd} / \mathrm{Co}_{3} \mathrm{O}_{4}-\mathrm{CeO}_{2}$ catalysts: Synthesis, characterization and mechanistic study of their catalytic properties for lowtemperature $\mathrm{CO}$ oxidation // J. Catal. 2008. - V. 254. - P. 310-324.

5. Hou X.D., Wang Y.Zh., Zhao Y.X. Effect of $\mathrm{CeO}_{2}$ doping on structure and catalytic performance of $\mathrm{Co}_{3} \mathrm{O}_{4}$ catalyst for lowtemperature $\mathrm{CO}$ oxidation // Catal. Lett. 2008. - V. 123. - P. 321-326.

6. Dhakad M., Mitshuhashi T., Rayalu S. $\mathrm{Co}_{3} \mathrm{O}_{4}-\mathrm{CeO}_{2}$ mixed oxide-based catalytic materials for diesel soot oxidation // Catal. Today. - 2008. - V. 132. - P. 188-193.

7. Todorova S., Kadinov G., Tenchev K. et al. $\mathrm{Co}_{3} \mathrm{O}_{4}+\mathrm{CeO}_{2} / \mathrm{SiO}_{2}$ catalysts for n-hexane and CO oxidation // Catal. Lett. - 2009. V. 129. - P. 149-155.

8. Firsova A.A., Khomenko T.I., Il'ichev A.N., Korchak V.N. Co oxidation with oxygen in the presence of hydrogen on $\mathrm{CoO} / \mathrm{CeO}_{2}$ and $\mathrm{CuO} / \mathrm{CoO} / \mathrm{CeO}_{2}$ catalysts // Kinet. Catal. 2008. - V. 49, N 5. - P. 682-691.

9. Rico-Pérez V., Parres-Esclapez S., IllánGómez M.J. et al. Preparation, characterisation and $\mathrm{N}_{2} \mathrm{O}$ decomposition activity of honeycomb monolith-supported
$\mathrm{Rh} / \mathrm{Ce} 0.9 \mathrm{Pr} 0.1 \mathrm{O}_{2}$ catalysts // Appl. Catal. B: Environmental. - 2011. - V. 107. - P.18.

10. Solov'ev S.A., Kurilets Ya.P., Orlik S.N. Effect of a second $\gamma-\mathrm{Al}_{2} \mathrm{O}_{3}$ support on the physicochemical characteristics of catalysts for $\mathrm{CO} / \mathrm{NO}_{\mathrm{x}} / \mathrm{C}_{\mathrm{n}} \mathrm{H}_{\mathrm{m}}$ three-way conversions // Theor. Experim. Chem. - 2003. - V. 39, N 1. - P. 58-63 (in Russian).

11. Boichuk T.M., Orlik S.N., Struzhko V.L. Reduction of $\mathrm{N}_{2} \mathrm{O}$ and NO over H-ZSM-5and $\mathrm{ZrO}_{2}$-Supported Iron- and CobaltContaining Catalysts // Rus. J. Appl. Chem. - 2010. - V. 83, N 10. - P. 1742-1749 (in Russian).

12. Nedil'ko S.A. Synthesis, Structure and Properties of Iso- or Heterosubstituted Complicated Oxides Containing Rare Earth Elements and Transition Metals: Thesis for the academic degree Doctor of Chemical Sciences, Kyiv (1994) (in Ukrainian).

13. Liu Ch., Luo L., Lu X. Preparation of mesoporous $\mathrm{Ce} 1-\mathrm{xFe}_{\mathrm{x}} \mathrm{O}_{2}$ mixed oxides and their catalytic properties in methane combustion // Kinet. Catal. - 2008. - V. 49, N 5. - P. 676-681.

14. Xue L., Zhang Ch., He $H$. Catalytic decomposition of $\mathrm{N}_{2} \mathrm{O}$ over $\mathrm{CeO}_{2}$ promoted $\mathrm{Co}_{3} \mathrm{O}_{4}$ spinel catalyst // Appl. Catal. B: Environmental. - 2007. - V.75, N 3-4. P. 167-174.

15. Liotta L.F., Di Carlo G., Longo A. et al. Support effect on the catalytic performance of $\mathrm{Au} / \mathrm{Co}_{3} \mathrm{O}_{4}-\mathrm{CeO}_{2}$ catalysts for $\mathrm{CO}$ and $\mathrm{CH}_{4}$ oxidation // Catal. Today. - 2008. V. 139. - P. 174-179.

16. Jansson J., Skoglundh M., Fridell E. et al. A mechanistic study of low temperature CO oxidation over cobalt oxide // Top. Catal. 2001. - V. 16-17. - P. 385-389.

17. Liu Zh.P., Нu. P. CO oxidation and NO reduction on metal surfaces: density functional theory investigations // Top. Catal. - 2004. - V. 28, N 1-4. - P. 71-78.

Received 26.11.2012, accepted 18.01.2013 


\section{Вплив складу і методу приготування (Pd), Co, Ce, $\mathrm{Zr}$-метал-оксидних каталізаторів на їх активність в реакціях відновлення оксидів азоту(I), (II) монооксидом вуглецю}

\section{Т.М. Бойчук, П.І. Кірієнко, С.М. Орлик, С.О. Соловйов}

Інститут фізичної хімії ім. Л.В. Писаржевського Національної академії наук Украӥни np. Науки, 31, Київ, 03039, Україна, boichuk_tm@ukr.net

В реакиіях відновлення оксидів азоту(I),(II) $\mathrm{CO}\left(\mathrm{CO}+\mathrm{NO}, \mathrm{N}_{2} \mathrm{O}+\mathrm{NO}+\mathrm{CO}\right)$ серед вивчених (Pd), Co-,Се- Zr-оксидних каталізаторів, зокрема на структурованих носіях з кордієриту, більшу активність виявив каталізатор, отриманий иляхом одночасного нанесення оксидів церію $i$ кобальту, що обумовлено зростанням рухливості поверхневого кисню і дисперсністю компонентів каталітичної композииії.

\section{Влияние состава и метода приготовления (Pd), Co, Ce, $\mathrm{Zr}$-металл-оксидных катализаторов на их активность в реакциях восстановления оксидов азота (I), (II) монооксидом углерода}

\section{Т.М. Бойчук, П.И. Кириенко, С.Н. Орлик, С.А. Соловьев}

Институт физической химии им. Л.В. Писаржевского Национальной академии наук Украины пр. Науки, 31, Киев, 03039, Украина, boichuk_tm@ukr.net

В реакииях восстановления оксидов азота(I),(II) $\mathrm{CO}\left(\mathrm{CO}+\mathrm{NO}, \mathrm{N}_{2} \mathrm{O}+\mathrm{NO}+\mathrm{CO}\right)$ среди изученных

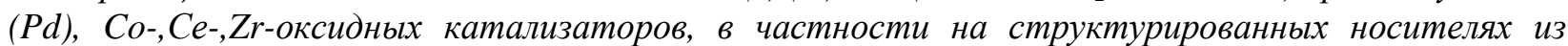
кордиерита, большую активность проявил катализатор, приготовленныгй путем одновременного нанесения оксидов иерия и кобальта, что обусловлено увеличением подвижности поверхностного кислорода и дисперсности компонентов каталитической композиции. 